\title{
Neutrality of Narrative Discussion in Annual Reports of UK Listed Companies
}

\author{
Venancio Tauringana \\ Senior Lecturer in Accounting and Finance \\ School of Finance and Law, Bournemouth University \\ $\&$ \\ Gin Chong \\ Professor of Accounting \\ Southampton Business School \\ Southampton Institute \\ Email: gin.chong@solent.ac.uk
}

Address for correspondence: Dr Venancio Tauringana, Senior Lecturer in Accounting and Finance, Bournemouth University, Fern Barrow, Poole, Dorset BH12 5BB, England. Email:vtauringana@bournemouth.ac.uk

\section{Acknowledgement:}

We would like to acknowledge the valuable and positive comments and feedback from participants at the 2003 British Accounting Association South West Accounting Group, held at the University of Glamorgan, Wales, UK. We are also indebted to the valuable comments and suggestions by Rob Day (Bournemouth University) and Musa Mangena (University of Bradford). 


\section{Neutrality of Narrative Discussion in Annual Reports of UK Listed Companies}

\section{Summary}

This paper reports the results of an investigation into the neutrality of the narrative discussion of financial performance and position, as evidenced in 179 annual reports of UK listed companies. Neutrality of narrative discussion was determined by comparing the average proportions of good and bad news contained in the narrative and statutory accounts sections of the annual reports. The results of a comparison of the proportion of good news in the two sections of the annual reports suggest that the narrative sections contained a significantly higher proportion of good news than the statutory accounts sections. Comparison of proportions of bad news, however, indicates that the narrative sections contained a significantly lower proportion of bad news compared to the statutory accounts sections. Finally, the results also suggest that the proportion of good news as compared to bad news in the narrative sections is significantly higher than the proportion of good news compared to bad news in the statutory accounts section. The results are consistent with the suggestion that company management highlights good news in narrative discussions. The implications of the findings for company management, users, auditors and regulators are discussed. 


\section{Introduction}

Annual reports in the UK consist of the narrative and statutory accounts sections. The only legal requirement for the narrative section is the inclusion of the directors' report. Most listed companies, however, also include the chairman's statement and the Operating and Financial Review (OFR) on a voluntary basis. For the statutory accounts section, the Companies Act 1985 requires the inclusion of the profit and loss account, balance sheet and notes to the accounts. In addition, Financial Reporting Standard (FRS) 1 also requires companies to include a cash flow statement as part of the financial statements.

The principal objectives of the narrative section are to supplement the financial information in the financial statements with discussions and explanations about the company's activities and its future, and to provide details of other non-financial matters (PricewaterhouseCoopers, 1999). In other words, the purpose of the narrative section is to complement financial statements so as to provide the user of financial statements with a complete picture of the company's financial performance and position. For example, the Companies Act 1985 requires the discussion of research and development activities and significant changes in the fixed assets of the company during the year. Such information not only refers readers to changes in monetary figures in the statutory accounts section but may also provide further information such as the reasons for the expenditure on research and development and its likely effect on future results.

There is, however, a general consensus that the narrative discussion of the company's financial position and performance needs to be neutral in terms of highlighting both good and bad news that has affected or may affect the performance of the company. 
If the discussion is not neutral it may not be useful to the users. Neutrality in narrative discussion is especially important to potential investors with little or no knowledge of accounting, who rely on the narrative section of the annual report (see for example, Lee and Tweedie, 1975; Wilton and Tabb, 1978; Winfield, 1978; and Bartlett and Chandler, 1997). Even sophisticated investors, such as investment analysts, will not be able to value a company accurately if the narrative discussion is biased.

The importance attached to ensuring neutrality of narrative information is reflected in the various mandatory and non-mandatory pronouncements. For example, the Companies Act 1985 requires a 'fair review of development of the business and its subsidiary undertakings during the financial year and their position at the end of it’ [s234 (1) (a)]. The Accounting Standards Board's (ASB) (1999) Statement of Principles requires financial information to be reliable. One element of reliability is neutrality. Financial information is not neutral if it has been selected or presented in such a way as to influence the making of a decision or judgement in order to achieve a predetermined result or outcome. Finally, the Operating and Financial Review (1993), although voluntary, suggests that one of the essential features of management discussion of operations and financial position is that 'it should be balanced and objective, dealing even-handedly with both good and bad aspects'.

Despite the need to ensure neutrality of narrative discussion of the financial position and performance of the company, problems with the current legislative framework on narrative discussion may lead to selectivity in what is discussed in the narrative section. First, the wording relating to what directors must discuss in the directors' report is too lax. For example, the Companies Act 1985 [s234 (2)] states that 'the principal activities 
of both the company and its subsidiaries during the year, and any details of any significant changes in those activities, should be stated'. What is 'principal' or 'significant' is, however, not defined by the Act. Secondly, despite requiring information contained in the directors' report to be sufficient in quantity and quality to satisfy the reasonable expectations of the readers, there is no audit requirement to ensure that this is the case. The only requirement is for auditors to carry out investigations to determine whether or not the information contained in the directors' report is consistent with the financial statements. Finally, directors are at liberty to include any other narrative information outside the mandatory directors' report, such as the chairman's statement, finance director's report and the Operation and Finance Review.

The absence of strict requirements on what directors should discuss in relation to the financial position and performance of the company gives rise to the concern that company directors may seize the opportunity to present themselves in a more favourable light. For example, Straw et al (1983) examined the letters to shareholders of companies that had experienced an increase and a decrease in financial performance in terms of earnings per share. They found that the companies were more likely to highlight positive rather than negative financial performance. Further, Beattie and Jones (1992) also found that companies were significantly more likely to include graphs to highlight good rather than bad performance.

The objective of this study is to investigate whether company management of UK listed companies is neutral in the narrative discussion of the financial performance and position contained in the statutory accounts (profit and loss account and balance sheet) in respect of both good and bad news. The study is important to a number of annual report 
stakeholders. For example, for company management, findings that indicate a bias in narrative discussion may result in more regulation of the narrative part of the annual report. More regulation will mean objective information being available to the users of annual reports. Finally, the findings of biased narrative discussion may also mean that in future auditors may well have to assume a greater role in ensuring neutrality of narrative discussion.

The remainder of the paper is organised as follows: The following section is a discussion of the UK narrative discussion framework. Section 3 is a review of literature, which forms the basis of the hypotheses. The research methodology, which gives details of the sample and the results of a questionnaire, follows this. The results of the study are presented and discussed in Section 5. The final section is a conclusion, highlighting implications and limitations.

\section{The UK narrative discussion framework}

The narrative section of annual reports in the UK may consist of a chairman's statement, Operating and Financial Review, the finance director's review, and the directors' report. The Companies Act 1985 only requires the inclusion of the directors' report. For example, the Companies Act 1985 requires that 'the amount (if any) that the directors recommend should be paid as dividend must be stated' [s234 (1) (b)]. Further, the Companies Act 1985 also states that 'particulars of any important events affecting the company or any of its subsidiaries that have occurred since the end of the financial year must be disclosed [7 Sch 6 (a)]. Finally, Companies Act 1985 also requires disclosure to be made in respect of directors' interest in shares or debentures of the company or any body corporate of the same group [s 325]. 
In addition, the London Stock Exchange (1999) listing rules (LR) also stipulate further requirements that listed companies must include in the directors' report. The listing rules require that the directors' report for listed companies must state the unexpired term of the service contracts of any director who is proposed for re-election at the forthcoming Annual General Meeting. If the directors proposed for re-election do not have service contracts, the directors' report must state the fact [LR16.8, 16.12]. Further, the listing rules also state that 'a statement should be given of particulars of the nature and extent of the interests of any person, in any holdings of three per cent or more of the nominal value of any class of capital carrying rights to vote in all circumstances at general meetings of the company. The statement must be made at a date not more than one month prior to the date of notice of the annual general meeting' [LR12.43]. Finally, the listing rules also require disclosure of transactions with controlling shareholders, waiver of dividends and compliance with the Combined Code.

In addition to the mandatory information to be included in the directors' report, the ASB (1993) issued the Operating and Financial Review, which is voluntary. The aim was to extend existing best practice by providing a framework within which directors could share the company's financial performance with stakeholders. Some of the essential features of the OFR are that it should:

- be written in a clear style and as succinctly as possible;

- be readily understandable by the general reader of annual reports and include only matters that are likely to be significant to investors;

- be balanced and objective, dealing even-handedly with both good and bad aspects;

- contain analytical discussion rather than merely numerical analysis; and

- make it clear how ratios or other numerical information given relate to the financial statements.

The OFR also recommends a discussion of significant features of the operating performance for the period covered by the financial statements. This can cover all 
aspects of the profit and loss account such as the level of profit on ordinary activities before taxation, the levels of capital expenditure, profit for the financial year, total recognised gains and losses, dividends and earnings per share, capital structure and treasury policy, taxation, funds from operating and other sources of cash, liquidity and the balance sheet value.

\section{Review of literature}

There is considerable debate and many assumptions as to how managers behave in financial reporting. Most academics have seized on the agency theory based on the seminal work by Jensen and Meckling (1976). The theory is concerned with the principal-agent problem in the separation of ownership and control of the firm, between different suppliers of capital (Smith and Warner, 1979), and in the separation of risk bearing firms (Fama and Jensen, 1983). At the heart of agency theory is the assumption that managers act so as to maximise utility. Jensen and Meckling (1976) illustrated the utility maximisation assumption by comparing the behaviour of a manager when he owns all the shares in the company and his behaviour when he owns some shares in the company. They argue that if a wholly-owned company is managed by the owner, operating decisions are attributable to the owner, and the operating profits accruing are likely to be more than those that are attributable to the owner if the firm is managed by the agent.

Agency theory is, however, not without its critics. For example, Metzger et al. (1986) note that business agency was originally a legal concept defined as a two-party relationship in which one party (the agent) is authorised to act on behalf of, and under the control of, the other party (the principal). Metzger et al. (1986) add that the laws of 
agency imposed specific duties of loyalty on the agent which Clark (1985) identified as a ‘fiduciary duty of loyalty’ and which in total help to deter abuse of managerial (agency) discretion. Duska (1992) states that since the first application of the agency-principal relationship to commercial ventures required loyalty, the concept of agency logically implied loyalty. He further argues that economists dropped the notion of loyalty because the view of human nature that they adopted was the view of the self-interested rational maximizer, a view incompatible with any desire to be bounded by loyalty to a principal. Duska (1992) however, suggests that managers act out of self-interest to an extent but not in all cases. He states that 'clearly there is an extent to which Smith (1776) and his followers are right. Human beings are essentially selfish and will not always look out for the interest of others but there are times when they will set aside their own interest and act on behalf of others', (p. 148 ).

Despite the inconclusive nature of the debate on whether managers act out of selfinterest, a number of studies in financial reporting using agency theory have largely confirmed the axioms of agency theory. For example, studies of accounting choices such as Hagerman and Zmijewski (1979) found evidence that managers chose accounting policies that increased their bonuses. Disclosure studies (Chow and Wong-Boren, 1987 and Botosan and Harris, 2000) also suggest that managers behave in a self-interested manner. Further, findings by Beattie and Jones (1992) that managers are likely to use graphs in the annual report if their companies have performed well is further evidence that managers sometimes look after their own interests. Finally, Straw et al. (1983) found that high performing companies place an overwhelming emphasis on positive events. Surprisingly, they also found that even low performing companies emphasised positive events. Clearly, such evidence suggests that managers do not always report financial 
information in an unbiased way. Based on this discussion the following three hypotheses were derived:

$H_{1}$ The narrative sections of the annual reports of UK listed companies contain a significantly higher proportion of good news compared to the proportion of good news contained in the statutory accounts sections.

$\mathrm{H}_{2}$ The narrative sections of annual reports of UK listed companies contain a significantly lower proportion of bad news compared to the proportion of bad news contained in the statutory accounts sections.

$H_{3} \quad$ The proportion of good to bad news contained in the narrative sections of annual reports of UK listed companies is significantly higher than the proportion of good to bad news contained in the statutory accounts sections.

\section{Research methodology}

\subsection{Sample}

A sample of 240 companies, representing $20 \%$ of all UK non-financial companies listed on the London Stock Exchange as at 31 December 2001, was randomly selected. A letter was sent to all these companies requesting their annual reports. Thirty-nine companies did not respond to the initial and two follow up requests and nine companies were eliminated because they had changed their accounting periods. Since the investigation required two years' data, thirteen companies were removed because they had been listed for less than two years. This left 179 companies. This paper reports on the results of an analysis of the annual reports of these 179 companies. 


\subsection{Methodology}

Two research methods were employed in this research. The first one was a questionnaire survey of finance directors to determine what constitutes good and bad news. The second research method was content analysis of the annual report. This research method involved comparing the results of the items listed in appendix I for the year 2001 and 2000 to determine whether there had been an increase or decrease. The objective was to find out, using the results of a survey of finance directors, whether the changes to those items between the years 2000 and 2001 constituted good or bad news. The narrative section of each annual report was then read to determine how much of the good and bad news contained in the profit and loss and balance sheet was discussed. The detailed procedures are discussed in the relevant sections below.

\subsubsection{Survey of finance directors}

The survey was based on a questionnaire listing all the items that are required to be disclosed in the profit and loss and balance sheet in terms of the Companies Act 1985, Accounting Standards and the London Stock Exchange listing rules. The questionnaire was pilot tested with five practising accountants. This resulted in the elimination of a

number of items. The final version of the questionnaire consisted of a total of 36 items. The first 18 items relate to the items found in the profit and loss account and the last 18 items to those found in the balance sheet. The questionnaire was sent to 30 randomly selected finance directors of the FTSE 100 companies to determine their views, on a scale of 1 to 5 (1 suggesting bad news and 5 good news), on whether an increase in the amounts for the 36 items from the year 2000 to 2001 constituted bad or good news. Any item with a ranking of below 3 was classified as bad news and that with a ranking above 
this figure as good news. After two reminders five usable responses had been received making a response rate of just under $17 \%$.

The descriptive statistics of all the items are presented in Table 1 . The results of the ranking of the profit and loss items suggest that finance directors surveyed view an increase in retained earnings and turnover as good news, as reflected in the high mean scores of 4.8 and 4.6 respectively. An increase in gross profit, profit for the year, and dividends is also viewed by finance directors as good news. The increase in loss on disposal of discontinued operations, net operating expenses and provision for loss on discontinued operations is regarded as representing bad news by the finance directors who responded to the survey.

The results of the ranking of balance sheet items by finance directors suggest that an increase in fixed assets, share premium and the retained profit and loss account represent good news. The mean ranking of all these items is 4.2. The finance directors also ranked an increase in tangible and intangible assets, debtors and cash as good news. The increase in provision for taxation, bank overdraft, creditors due after one year and debentures is seen as bad news as indicated by the mean scores of 1.8 for each of these items.

The findings reported in this section are generally consistent with the expectations from finance literature that regards increase in cost as bad news and revenue as good news. However, it was important to obtain some empirical evidence to confirm the assumptions. A large-scale survey of finance directors was deemed unnecessary in the light of confirmatory evidence from the small sample. A much larger survey on the same subject largely confirmed the findings reported above but is a subject of a different paper. 
Table 1 Descriptive statistics of good and bad news ( $\mathrm{N}=5)$

\begin{tabular}{|l|c|c|c|r|}
\hline & Min & Max & Mean & $\begin{array}{c}\text { Std. } \\
\text { Deviation }\end{array}$ \\
\hline Turnover & 4.00 & 5.00 & 4.60 & .5477 \\
Cost of sales & 1.00 & 2.00 & 1.40 & .5477 \\
Gross profit & 3.00 & 5.00 & 4.00 & .7071 \\
Net operating expenses & 1.00 & 2.00 & 1.60 & .5477 \\
Operating profit & 4.00 & 5.00 & 4.40 & .5477 \\
Profit on property sale & 3.00 & 4.00 & 3.60 & .5477 \\
Provision for loss on operations to be & 1.00 & 3.00 & 1.80 & .8367 \\
discontinued & & & & \\
Loss on disposal of discontinued & 1.00 & 2.00 & 1.40 & .5477 \\
operations & 3.00 & 5.00 & 4.00 & .7071 \\
Profit before interest & 1.00 & 3.00 & 2.00 & .7071 \\
Interest payable & 4.00 & 5.00 & 4.20 & .4472 \\
Profit before tax & 1.00 & 3.00 & 2.00 & .7071 \\
Taxation & 4.00 & 5.00 & 4.40 & .5477 \\
Profit after tax & 2.00 & 3.00 & 2.20 & .4472 \\
Minority interests & 4.00 & 5.00 & 4.40 & .5477 \\
Profit for the year & 4.00 & 5.00 & 4.40 & .5477 \\
Dividends & 4.00 & 5.00 & 4.80 & .4472 \\
Retained profit & 3.00 & 5.00 & 4.00 & .7071 \\
Earnings per share & 3.00 & 5.00 & 4.20 & .8367 \\
Fixed assets (total) & 3.00 & 5.00 & 4.00 & .7071 \\
Tangible assets & 3.00 & 5.00 & 4.00 & .7071 \\
Intangible assets & 3.00 & 4.00 & 3.60 & .5477 \\
Current assets (total) & 3.00 & 4.00 & 3.60 & .5477 \\
Stocks & 3.00 & 5.00 & 4.00 & .7071 \\
Debtors & 3.00 & 5.00 & 4.00 & .7071 \\
Cash & 2.00 & 3.00 & 2.60 & .5477 \\
Prepayments & 2.00 & 3.00 & 2.20 & .4472 \\
Creditors due in one year & 1.00 & 2.00 & 1.80 & .4472 \\
Provision for tax & 2.00 & 3.00 & 2.20 & .4472 \\
Accrued charges & 1.00 & 2.00 & 1.80 & .4472 \\
Bank overdraft & 3.00 & 5.00 & 4.00 & .7071 \\
Net current assets & 1.00 & 2.00 & 1.80 & .4472 \\
Creditors due after one year & 1.00 & 2.00 & 1.80 & .4472 \\
Debentures & 3.00 & 2.00 & .7071 \\
Share capital & 5.00 & 4.20 & .4472 \\
Share premium & 5.00 & 4.20 & .4472 \\
Profit and loss & & & \\
\hline
\end{tabular}

Key:
1. bad news
2. slightly bad news
3. neither bad news or good news
4. slightly good news
5 . good news 


\subsubsection{Determining the proportion of 'good' and 'bad' news}

To determine the proportions of good and bad news in the statutory accounts section of each annual report the scoring sheet (see appendix II) was used. Based on the results of the survey of directors each of the 36 items was scored as either good news or bad news. This was determined by examining whether the 2001 figures represented an increase or decrease compared to those of the previous year (2000). If for example, turnover had gone up a ' $G$ ' was placed alongside that item in the scoring sheet to indicate that for that company there was good news in respect of turnover. If on the other hand turnover had gone down, a ' $\mathrm{B}$ ' was placed alongside turnover to indicate that was bad news. The procedure was carried out for each of the 36 items in a similar way. In the end the number of 'Gs' and 'Bs' was counted. If it turned out that the number of 'Gs' was 18 and the number of 'Bs' was 18, the proportion of good and bad news was recorded as 50\% good news and 50\% bad news respectively. This was based on dividing 18 by the total of 36 items in each case. If any of the 36 items in appendix II was not applicable to one company then the denominator was reduced by the total of inapplicable items.

To establish the proportions of good and bad news being discussed in the narrative section of the annual reports a scoring sheet (see appendix III) was used. The procedure entailed going through the narrative section of each company's annual report (chairman's statement, operating and financial review and directors' report) and identifying all statements discussing any of the 36 items. If the item discussed was coded as representing good news in the statutory accounts section it was similarly coded 'G' to signify that the statement was discussing good news contained in the statutory accounts. 
Similarly, when a statement was found that was discussing an item that was coded as representing bad news in the statutory accounts it was coded ' $\mathrm{B}$ ' representing bad news. As with the statutory accounts section, the final procedure to determine the proportion of good news and bad news was adding all 'Gs' and 'Bs' and expressing the total of each as a percentage of the sum of all 'Gs' and 'Bs'. However, since it is unrealistic to expect each company to discuss all 36 items, the proportion of good or bad news was determined by dividing the total number of ' $G$ ' by the total of both 'Gs' and 'Bs'. This means that, for example, if the company discussed just 10 out of the 36 items, and 5 items related to good and the other 5 to bad news, the proportion of good news would be $50 \%$ and bad news $50 \%$.

\subsection{Determination of neutrality of narrative discussion}

To test hypothesis 1 , which states that narrative sections contain a significantly higher proportion of good news than the statutory accounts sections, required comparing the average (mean) proportions of good news contained in the narrative sections and statutory accounts sections of the annual reports of the 179 companies. The logic is that, given the 36 items under investigation, if a company had $50 \%$ of the items representing 'good' news in the statutory accounts section, then the discussion in the narrative section of the annual report should contain an average of $50 \%$ relating to good news items. If in the narrative section the percentage of discussion of good news was significantly higher than $50 \%$, that would suggest a bias in the narrative discussion in favour of good news.

To test hypothesis 2, which states that narrative sections contain a significantly lower proportion of bad news than the statutory accounts sections, required comparing the 
average proportion of bad news in the narrative section and in the statutory accounts section. If the average proportion of bad news contained in the statutory accounts was significantly higher than that contained in the narrative section that would suggest that management was discussing very little of their 'bad' news.

Finally, hypothesis 3, which states that the proportion of good to bad news contained in the narrative section is significantly higher that the proportion of good to bad news contained in the statutory accounts section, was tested. This was tested by comparing proportions of good to bad news contained in the narrative sections to the proportion of good to bad news contained in the statutory accounts sections.

\section{Results and discussion}

\subsection{Descriptive statistics}

Table 2 presents the descriptive statistics of the proportions of good news contained in the narrative and statutory accounts sections of the annual reports. The results show that the mean (average) for the narrative section is 0.7203 compared to 0.6302 for the statutory accounts section. This suggests that the proportion of narrative discussion reflecting good news is higher than the proportion of good news found in the statutory accounts. This in turn suggests a bias in the narrative discussion in favour of good news. The minimum scores for the narrative and the statutory accounts sections are .00 and .17 respectively. The maximum score of 1.00 for the narrative section indicates that at least one company chose to discuss all good news and none of the bad news. The results in Table 2 also show a greater variation in the distribution of the proportion of good news in the narrative section compared to the statutory accounts section as reflected by the differences in standard deviations of .2714 and .1982 
respectively. This may be explained by the fact that companies are largely free to decide which items they discuss in the narrative section whilst items to be included in financial statements are prescribed by law.

Table 2 Descriptive statistics of good news

Proportions in narrative and statutory accounts sections of the annual reports

$\begin{array}{lccccl} & \mathrm{N} & \text { Mean } & \text { Min } & \text { Max } & \text { Std Dev } \\ \text { Narrative } & 179 & .7203 & .00 & 1.00 & .2714 \\ \text { Statutory } & 179 & .6302 & .17 & .92 & .1982\end{array}$

The descriptive statistics for the proportion of bad news in the narrative sections and statutory accounts sections are presented in Table 3. The mean score for the narrative section is 0.2685 compared to 0.3698 for the statutory accounts section. This suggests that the companies are discussing less bad news than that contained in the statutory accounts. This in turn suggests a bias in the narrative disclosures against bad news. The minimum proportion of bad news for the narrative and statutory accounts sections are .00 and .08 respectively. This suggests that at least one company did not discuss any bad news. The results in Table 3 also show a greater variation in the narrative section compared to statutory accounts section as indicated by the variations in the two standard deviations.

Table 3 Descriptive statistics of bad news

Proportions in narrative and statutory accounts sections of the annual report

$\begin{array}{lcllcc} & \mathrm{N} & \text { Mean } & \text { Min } & \text { Max } & \text { Std Dev } \\ \text { Narrative } & 179 & .2685 & .00 & 1.00 & .2619 \\ \text { Statutory } & 179 & .3698 & .08 & .83 & .1982\end{array}$




\subsection{T-test results}

The one-sample t-test results for neutrality of narrative discussion in respect of good news are presented in Table 4. The test shows whether the differences in the mean of the proportion of good news in the narrative sections and the proportion of good news in the statutory accounts sections, are statistically different from zero. The two-tailed test is used so that either a positive difference or negative difference can be detected. The t-statistic is 4.737 and is significant at the 0.01 level. This suggests that there is a positive significant difference between the average proportion of good news contained in the narrative section and the average proportion of good news contained in the statutory accounts section. The implication is that the proportion of good news in the narrative section is greater than the proportion of good news contained in the statutory accounts.

Table 4 One-sample statistics for neutrality of narrative discussion in respect of good news (test value $=0$ )

\begin{tabular}{lllcllll} 
Variable & t-statistic & df & Sig. (2-tailed) & Mean & Std Dev & \multicolumn{2}{c}{$\begin{array}{c}\text { 95\% confidence } \\
\text { interval of the } \\
\text { difference }\end{array}$} \\
Good news & 4.737 & 178 & .00 & .1794 & .5067 & $\begin{array}{l}\text { Lower } \\
\text { Upper }\end{array}$ \\
\hline
\end{tabular}

Table 5 presents the one sample t-test results of neutrality in respect of bad news. A two-tailed significant test was also employed to detect any difference in the average proportions of bad news contained in the narrative and statutory accounts sections of the annual reports. The t-statistic is -6.245 and the mean score difference is -.2957 . In other words the difference between the average proportion of bad news in the narrative section and that in the statutory accounts section is negative. This suggests that companies discuss a lesser proportion of bad news in the narrative section 
compared to what is contained in the statutory accounts. The difference is significant at 0.01 level.

Table 5 One-sample statistics for neutrality of narrative discussion of bad news (test value $=0$ )

\begin{tabular}{|c|c|c|c|c|c|c|c|}
\hline Variable & t-statistic & $\mathrm{df}$ & Sig. (2-tailed) & Mean & Std Dev & $\begin{array}{r}95 \% \text { c } \\
\text { interv } \\
\text { diffe }\end{array}$ & $\begin{array}{l}\text { idence } \\
\text { of the } \\
\text { ice }\end{array}$ \\
\hline Bad news & -6.245 & 178 & .00 & -.2957 & .6336 & $\begin{array}{c}\text { Lower } \\
-.3892\end{array}$ & $\begin{array}{c}\text { Upper } \\
-.2023\end{array}$ \\
\hline
\end{tabular}

Finally, the results of a test to determine whether there was a difference in the average proportions of good to bad news contained in the narrative sections compared to the average proportions of good to bad news in the statutory accounts sections, are presented in Table 6. The results show a mean of .9078 with a standard deviation of .6642. The t-statistic is 18.287 and is significant at the 0.01 level. This suggests that the proportion of good to bad news contained in the narrative section of the annual reports is significantly greater than the proportion of good news to bad contained in the statutory accounts section.

Table 6 One-sample statistics for neutrality of narrative discussion of good and bad news (test value $=0$ )

\begin{tabular}{|c|c|c|c|c|c|c|c|}
\hline Variable & t-statistic & $\mathrm{df}$ & Sig. (2-tailed) & Mean & Std Dev & $\begin{array}{r}\text { 95\% Co } \\
\text { Interva } \\
\text { Differe }\end{array}$ & $\begin{array}{l}\text { fidence } \\
\text { of the } \\
\text { ce }\end{array}$ \\
\hline Good/bad news & 18.287 & 178 & .00 & .9078 & .6642 & $\begin{array}{l}\text { Lower } \\
.8099\end{array}$ & $\begin{array}{r}\text { Upper } \\
1.0058\end{array}$ \\
\hline
\end{tabular}

Overall the results of the t-test suggest that managers are biased in favour of good news and against bad news. The results are consistent with the literature discussed 
that suggests that company managers, in some cases, may be biased in presenting financial results especially when their reputation is at stake.

\section{$6 \quad$ Conclusions, implications and limitations}

The purpose of this paper was to investigate whether narrative discussion contained in the narrative section of annual reports of UK listed companies is neutral in respect of the financial results reported in the statutory accounts (profit and loss account and balance sheet). Neutrality of narrative discussion was determined by comparing the average proportion of good and bad news contained in statutory accounts with the average proportion of good and bad news contained in the narrative sections of the annual reports.

A survey was undertaken to determine what constitutes good and bad news in the statutory accounts. The results of a comparison of average proportions of good news contained in the narrative and statutory accounts sections suggest that the narrative sections contained a significantly higher proportion of good news than the statutory accounts sections. The results of a comparison of proportions of bad news in the two sections of the annual report suggest that the narrative sections contain a significantly lower proportion of bad news compared to the statutory accounts sections. Finally, the results also indicate that the proportion of good to bad news in the narrative sections is significantly higher than that of good to bad news contained in the statutory accounts sections. The conclusion of this investigation is that managers are not neutral in their narrative discussion. They are biased in favour of good news and against bad news. 
There are a number of policy implications for the current findings, if the results are confirmed by future research. For those who prepare annual reports, the findings of impartiality on their part may bring about undesirable consequences. These may include new legislation to compel management to be objective regarding both good and bad news. The purpose of the legislation would be to constrain their ability to choose which aspects of financial performance and position they discuss.

The findings that narrative discussions are biased also suggest that users, particularly the unsophisticated, are being 'fooled' since there is evidence that they do not understand financial statements and rely on narrative parts of the annual report (Lee and Tweedie, 1975 and Bartlett and Chandler, 1997). Whilst sophisticated users may not be 'fooled' by the biased narrative discussion, the bias means that they are denied the chance of a full explanation for poor performance.

For the regulators, the findings in this paper suggest that they need to take action to protect the users of financial statements who need neutral information to be able to make investment decisions. One way may be to make the OFR compulsory. The other route may be to introduce more prescriptive legislation to compel directors to provide a narrative discussion of particular items in the financial statements regardless of whether the outcome is regarded as good or bad by management.

The bias in narrative discussion may also have implications for auditors whose interest is to protect the stakeholders of the company. Bias in narrative discussion may increase the chances of auditors being sued. It may therefore be in the interest of the auditors to examine the narrative discussion to establish whether it is objective given the financial 
results. If auditors do not take such an initiative it may well be that the role will be forced upon them in future.

The conclusions and implications discussed above must be taken in the context of the limitations of the current study. Firstly, the determination of good and bad news is based on the views of 5 respondents although 30 were surveyed. However, the findings are consistent with finance literature and were also later confirmed in a larger survey that is the subject of a different paper.

A further limitation is that in certain circumstances an increase or decrease in expenses may not necessarily imply good news. For example, an increase in cost of sales may simply be a reflection of the increase in sales. This limitation can be alleviated by examining the relative increase in sales compared to the cost of sales. Increase in cost of sales would therefore be regarded as bad news if the percentage increase is more than the percentage increase in sales.

Further, the study is cross sectional rather than a trend analysis. Finally, the content analysis of the narrative was accomplished manually. Use of computer content analysis packages may help improve objectivity of the coding. Despite these limitations we still believe that the findings reported are significant and are likely to be confirmed by future research. 


\section{Bibliography}

Accounting Standards Board (1993), Operating and financial review; London; Accounting Standards Board.

Accounting Standards Board (1999), Statement of principles for financial reporting; London; Accounting Standards Board.

Bartlett, S.A. and Chandler, R.A . (1997), 'The corporate report and the private shareholder: Lee and Tweedie twenty years on’, British Accounting Review, Vol. 29, pp 245-261.

Beattie, V. and Jones, M.J . (1992), 'The use and abuse of graphs in annual reports: theoretical framework and empirical study', Accounting and Business Research, Vol. 22, No.88, pp 291-303.

Botosan, C.A. and Harris, M.S. (2000), 'Motivations for a change in disclosure frequency and its consequences: An examination of voluntary quarterly segment disclosures', Journal of Accounting Research, Vol. 38, No. 2, pp 329-353.

Chow, C.W. and Wong-Boren, A. (1987), 'Voluntary financial disclosure by Mexican corporations', The Accounting Review, Vol. 62, No.3, pp 533-541.

Clark, R.C. (1985), ‘Agency costs versus fiduciary duties’, In J. Pratt and R. Zeckhauser (eds.), Principals and agents: The structure of business, Boston, Mass.: Harvard Business School Press, pp 55-79.

Companies Act 1985. Companies Act 1985, Her Majesty’s Stationery Office. London.

Duska, R.F. (1992), 'Why be a loyal agent? A systematic ethical analysis', in Ethics and agency theory: An introduction, Bowie, N.E., and Freeman, E., (eds.), Oxford University Press.

Fama, E.F. and Jensen , M.C. (1983), 'Separation of ownership and control', Journal of Law and Economics, June, pp 301-325.

Hagerman, R.L. and Zmijewski, M.E. (1979), 'Some economic determinants of accounting policy choice’, Journal of Accounting and Economics, Vol. 1, pp 141-161.

Jensen, M.C. and Meckling, W.H. (1976), 'Theory of a firm: Managerial behaviour, agency costs and ownership structure', Journal of Financial Economics, Vol 3, No.1, pp 305-60.

Lee, T.A. and Tweedie, D.P. (1975), 'Accounting information: An investigation of private shareholder usage', Accounting and Business Research, Vol. 5, No. 20, pp 280291. 
London Stock Exchange. (1999). The listing rules, London Stock Exchange, London.

PricewaterhouseCoopers. ((1999), Student's manual of accounting: the guide to UK accounting law and practice, International Thomson Business Press.

Metzger, M., Bowie, N. and DeGeorge, R.T. (eds.). (1986), Business Law and Regulatory Environment, Homewood, III.: Richard D.Irwin.

Smith, A. (1776), An enquiry into the causes of wealth of nations, Canan, E (ed), New York: Random House, 1937.

Smith, C.W. and Warner, J. (1979), 'On financial contracting: An analysis of bond covenants. Journal of Financial Economics, Vol. 7, No. 1, pp 117-161.

Straw, B.M, McKechnie, P.I and Puffer, S.M. (1983), 'The justification of organisational performance', Administrative Science Quarterly, Vol. 28, No. 4, pp. 582-600.

Wilton, R. L. and Tabb, J.B. (1978), 'An investigation into private shareholder usage of financial statements in New Zealand’, Accounting Education, May, pp 171.

Winfield, R.R. (1978), 'Shareholder opinion of published financial statements' A paper presented at the Accounting Association of Australia and New Zealand, University of Otago, New Zealand. 


\section{Appendix I}

\section{Survey of finance directors' perception of good and bad news in annual reporting}

Instructions: You are given the following items of information that appear or could appear in your company's annual report. Can you please indicate by ticking the appropriate box, to what extent you believe an INCREASE in current year's figures over last year's figures represents GOOD or BAD news? In each case assume that the increase is material and the expectations by the users of your company's annual report was that the current year's figures would be the same as the previous year's figures.

Key:
1. bad news
3. neither bad news
4. slightly good news

2. slightly bad news nor good news

5. good news

\section{Profit and loss account}

1. Turnover

2. Cost of sales

3. Gross profit

4. Net operating expenses

5. Operating profit

6. Profit on sale of properties

7. Provision for loss on operations to be discontinued

8. Loss on disposal of discontinued operations

9. Profit on ordinary activities before interest

10. Interest payable 
11. Profit on ordinary activities before taxation

12. Tax on profit on ordinary activities

13. Profit on ordinary activities after taxation

$\begin{array}{lllll}1 & 2 & 3 & 4 & 5\end{array}$

14. Minority interests

$\begin{array}{lllll}1 & 2 & 3 & 4 & 5\end{array}$

15. Profit for the financial year

$\begin{array}{lllll}1 & 2 & 3 & 4 & 5\end{array}$

16. Dividends

$\begin{array}{lllll}1 & 2 & 3 & 4 & 5\end{array}$

17. Retained profit for the financial year

$\begin{array}{lllll}1 & 2 & 3 & 4 & 5\end{array}$

18. Earnings per share

$\begin{array}{lllll}1 & 2 & 3 & 4 & 5\end{array}$

\section{Balance sheet}

19. Fixed assets (total)

$\begin{array}{lllll}1 & 2 & 3 & 4 & 5\end{array}$

20. Tangible fixed assets (total)

$\begin{array}{lllll}1 & 2 & 3 & 4 & 5\end{array}$

21. Intangible fixed (total)

$\begin{array}{lllll}1 & 2 & 3 & 4 & 5\end{array}$

22. Current Assets (total)

$\begin{array}{lllll}1 & 2 & 3 & 4 & 5\end{array}$

23. Stocks

$\begin{array}{lllll}1 & 2 & 3 & 4 & 5\end{array}$

24. Debtors

$\begin{array}{lllll}1 & 2 & 3 & 4 & 5\end{array}$

25. Cash at bank and in hand

$\begin{array}{lllll}1 & 2 & 3 & 4 & 5\end{array}$

26. Prepayments

$\begin{array}{lllll}1 & 2 & 3 & 4 & 5\end{array}$ 
27. Creditors: amounts falling due within one year

28. Provision for corporation tax

29. Accrued charges

30. Bank overdraft

31. Net current assets

32. Creditors: amounts falling due after more than one year

33. Debentures

34. Share capital

35. Share premium

36. Profit and loss account

Could you please supply your details in the space provided below if you are willing to participate in a follow-up interview so that I can contact you to arrange for a mutually convenient time?

Name

Address

Telephone Fax Email

Thank you very much for your time. 


\section{Appendix II}

\section{Statutory Accounts section scoring sheet}

\section{Company Name}

\section{List of Items}

\section{Profit and loss account}

1. Turnover

2. Cost of sales

3. Gross profit

4. Net operating expenses

5. Operating profit

6. $\quad$ Profit on sale of properties

7. Provision for loss on operations to be discontinued

8. Loss on disposal of discontinued operations

9. Profit on ordinary activities before interest

10. Interest payable

11. Profit on ordinary activities before taxation

12. Tax on profit on ordinary activities

13. Profit on ordinary activities after taxation

14. Minority interests

15. Profit for the financial year

16. Dividends

17. Retained profit for the financial year

18. Earnings per share

\section{Balance sheet}

19. Fixed assets (total)

20. Tangible fixed assets (total)

21. Intangible fixed (total)

22. Current assets (total)

23. Stocks

24. Debtors

25. Cash at bank and in hand

26. Prepayments

27. Creditors: amounts falling due within one year

28. Provision for corporation tax

29. Accrued charges

30. Bank overdraft

31. Net current assets

32. Creditors: amounts falling due after more than one year

33. Debentures

34. Share capital

35. Share premium

36. Profit and loss account

Total

Good News

Proportion of Good News

Bad News

Proportion of Bad News

\section{Good/Bad News}
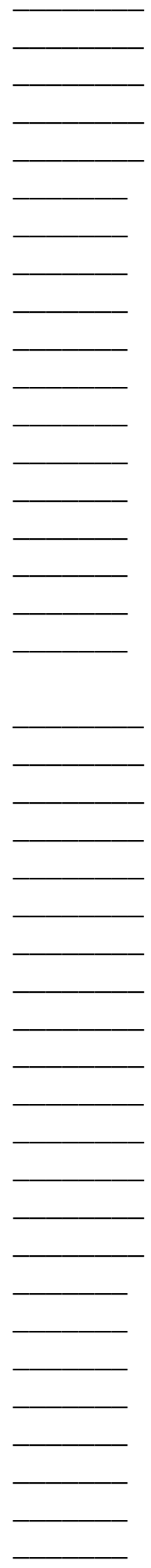


\section{Appendix III}

\section{Narrative section scoring sheet}

\section{Company Name}

\section{List of Items}

\section{Profit and loss account}

1. Turnover

2. Cost of sales

3. Gross profit

4. Net operating expenses

5. Operating profit

6. $\quad$ Profit on sale of properties

7. Provision for loss on operations to be discontinued

8. Loss on disposal of discontinued operations

9. Profit on ordinary activities before interest

10. Interest payable

11. Profit on ordinary activities before taxation

12. Tax on profit on ordinary activities

13. Profit on ordinary activities after taxation

14. Minority interests

15. Profit for the financial year

16. Dividends

17. Retained profit for the financial year

18. Earnings per share

\section{Balance sheet}

19. Fixed assets (total)

20. Tangible fixed assets (total)

21. Intangible fixed (total)

22. Current Assets (total)

23. Stocks

24. Debtors

25. Cash at bank and in hand

26. Prepayments

27. Creditors: amounts falling due within one year

28. Provision for corporation tax

29. Accrued charges

30. Bank overdraft

31. Net current assets

32. Creditors: amounts falling due after more than one year

33. Debentures

34. Share capital

35. Share premium

36. Profit and loss account

Total

Good News

Proportion of Good News

Bad News

Proportion of Bad News

\section{Good/Bad News}
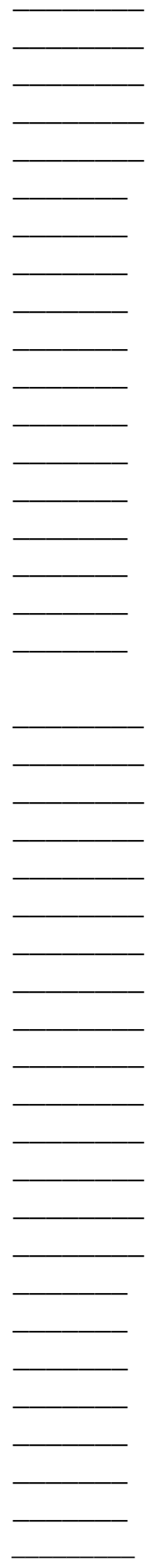